\title{
SENI PAKAIAN PADA KEBUDAYAAN MATARAM KUNO SEBAGAI SUMBER PEMBELAJARAN SEJARAH (STUDI IKONOGRAFI RELIEF CANDI BOROBUDUR)
}

\author{
Oleh: Prengki* \\ *Mahasiswa Program Studi Pendidikan Sejarah FKIP Universitas PGRI Palembang
}

\begin{abstract}
ABSTRAK
Candi Borobudur banyak menyimpan cerita tentang kehidupan manusia pada masa lampau salah satunya, seni pakaian pada kebudayaan Mataram Kuno. Data kesejarahan tersebut belum dimanfaatkan dalam pembelajaran sejarah. Permasalahan dalam penelitian ini adalah nilai sejarah apakah dari pakaian Pada kebudayaan Mataram Kuno yang dapat dimanfaatkan sebagai sumber pembelajaran sejarah?. Tujuan penelitian mengetahui seni pakaian pada kebudayaan Mataram Kuno. Metode dalam penelitian ini adalah deskriptif kualitatif yaitu proses menguji dan menganalisis kesaksian sejarah guna menemukan data yang akurat dan dapat dipercaya mendeskripsikan segala peristiwa atau kejadian yang terjadi pada masa sekarang dengan menggunakan pendekatan hasil ekstensi dua subjek penelitian dan partisipasi melalui pengamatan dan wawancara yang mendalam menggamberkan secara riset dan lengkap. Teknik pengumpulan data melalui observasi, dokumentasi dan wawancara. Hasil penelitian: masyarakat Mataram Kuno menggunakan pakaian berdasarkan peruntukan, waktu dan status sosial, memiliki 7 jenis pakaian masyarakat Mataram Kuno pada abad ke 9-11 Masehi.
\end{abstract}

Kata Kunci: Seni Pakaian, Kebudayaan Mataram Kuno, Sumber Pembelajaran Sejarah.

\section{A. PENDAHULUAN}

Menurut Handoyo, (2015:56) Setiap masyarakat memiliki kebudayaan dalam kehidupan masyarakat, kebudayaan merupakan hal yang sangat diperlukan kebudayaan merupakan pedoman dalam penyelenggaraan berbagai aktivitas kehidupan apakah sesungguhnya kehidupan itu? dalam menjelaskan pengertian kebudayaan, para ahli memberikan bermacam rumusan definisi Seperti. Kata "kebudayaan" berasal dari kata Sansekerta buddhaya, yaitu bentuk jamak dari buddhi yang berarti "budi" atau "akal". Dengan demikian ke-budaya-an dapat diartikan : "hal-hal yang bersangkutan dengan akal". Ada sarjana lain yang mengupas kata budaya sebagai suatu perkembangan dari kata majemuk budidaya, yang berarti "daya" dan "budi". Karena itu mereka membedakan "budaya" dan "kebudayaan". Demikianlah "budaya" adalah "daya" atau "budi" yang berupa cipta, karsa, dan rasa. Sedangkan "kebudayaan" adalah hasil dari cipta, karsa, dan rasa itu (Koentjaraningrat, 2009:146).

Selain itu kebudayaan menurut Goodenough dalam Keesing diartikan dalam dua arah pengertian yang berbeda, yaitu pola untuk prilaku dan pola dari prilaku. Oleh karena itu, kebudayaan sering diartikan dalam dua pengertian yang berbeda: pertama pola kehidupan, suatu masyarakat yang menyangkup kegiatan dan pengaturan material dan sosial yang berulang secarah teratur merupakan kekhususan suatu kelompok manusia tertentu; kedua kebudayaan merupakan sistem pengetahuan dan kepercayaan yang disusun sebagai pedoman manusia dalam mengatur pengalaman dan persepsi mereka, menentukan tindakan, dan memilih diantara alternatif yang ada.

\section{B. METODE PENELITIAN}

Dalam penelitian ini peneliti menggunakan metode penelitian deskriptif kualitatif, Sumber Data. Informan, Dokumen. Tempat penelitian di candi 
Borobudur dan SMA Nadhlatul Ulama Palembang. Teknik Pengumpulan Data: Wawancara Mendalam, Kajian Dokumen, Observasi Langsung. Teknik Cuplikan. penelitian ini menggunakan teknik cuplikan purposive sampling. Validitas Data. Validitas data sangat penting dalam proses pemaparan hasil penelitian, pembahasan dan penarikan simpulan. Dengan adanya validitas data triangulasi yang digunakan: triangulasi data, triangulasi metode.

\section{HASIL DAN PEMBAHASAN Hasil Penelitian}

Pada abad ke-8 telah berdiri sebuah kerajaan di Jawa Tengah, nama kerajaan yang beribukota di Medang I bumi Mataram itu kini lazim disebut dengan nama Mataram Kuno, Mataram Hindu, Mda, atau Medang. Terdapat dugaan, bahwa ibukota Mataram Kuno semasa pemerintahan Sanyaja tersebut terletak di Daerah Istimewa Yogyakarta. Hal ini yang melatarbelakangi penyebutan wilayah Yogyakarta sebagai Negeri Mataram, sebuah wilayah yang pada tahun 1587-1677 kembali menjadi pusat pemerintahan Mataram Baru (Mataram Islam) (Utami, 2014:29).

Mataram Kuno adalah kerajaan yang tergolong tua, kerajaan ini memiliki tradisi sastra Jawa yang kuat berbagai dokumen sastra Jawa Kuno banyak yang tercatat di era kerajaan, studi sejarah Jawa Kuno secara tertulis dimulai tanggal 25 Maret 804 , dengan ditemukannya prasasti Sukabumi yang berbunyi, pada tahun 726 penanggalan Saka dalam bulan caitra pada hari kesebelas paro terang, pada hari Haryang atau hari kedua dalam minggu yang berhari enam, Wage tau hari keempat dalam minggu berhari lima, saniscara atau hari ketujuh dalam minggu yang berhari tujuh, keterangan ini amat berharga berkaitan dengan validitas sumber penulisan historiografi lokal pada khususnya, sejarah nasional pada umumnya sumber penulisan sejarah Mataram Kuno, yaitu prasasti Mantyasih di
Kedu yang diterbitkan pada masa Rakai Watukumara Dyah Balitung yang berangka tahun 907, prasasti mantyasih menyebutkan para raja Mataram Kuno yaitu; 1) Rakai Mataram Sang Ratu Sanjaya, 2) Sri Maharaja Rakai Panangkaran, satu hal yang cukup mengagumkan bahwa pada zaman Jawa Kuno dahulu pendidikan humaniora mendapat tempat utama, soal-soal kesusastraan tidak menjadi monopoli kelas profesional terbatas saja, pendidikan puisi merupakan pendidikan yang harus diikuti oleh umum, lebih-lebih kalangan pegawai istana dan pemuka masyarakat (Utami, 2014:196-197).

\section{Klafikasi Sosial Masyarakat Mataram Kuno}

Struktur masyarakat Jawa Kuno dalam kesusasteraan seperti Nagarakratagama dan di dalam berbagai prasasti banyak sekali disebutkan tentang pembagian golongan masyarakat ke dalam kasta-kasta (caturwarna), yaitu kasta Brahmana, kasta Ksatrya, kasta Waisya dan kasta Sudra, mengenai pembagian kasta-kasta ini Pigeaud berpendapat bahwa yang ada di India tidak sesuai dengan kenyataan yang ada di Indonesia, Pigeaud membagi masyarakat Jawa Kuno ke dalam empat kelas yang terdiri dari kaum penguasa, kaum agama, orang biasa dan budak, dengan demikian masyarakat Jawa Kuno terbagi atas tiga golongan utama, yaitu golongan penguasa, golongan agama, dan golongan rakyat biasa. Seperti halnya dengan pembagian masyarakat ke dalam golongan-golongan maka De Casparis berpendapat bahwa adanya pembagian kasta yang dikenal di Indonesia ini peraturannya tidak sekeras yang terdapat di India, ia membagi masyarakat Jawa Kuno kedalam tiga golongan yaitu: golongan pertama yang terbesar jumlahnya adalah penduduk desa seluruhnya, golongan kedua adalah Sang Prabu dengan segenap kaum keluarganya dan mereka yang langsung tergantung kepada Sang Prabu, dengan 
mudah dapat kita sebut golongan keraton, golongan ketiga golongan agama, antara lain pedanda-pedanda di candi-candi, orang yang tinggal di wihara-wihara dan pegawaipegawai rendahannya (Depdikbud, 1990:961).

setiap Mengenai stratifikasi sosial ternyata
menampilkannya antara lain lewat pakaian, ada kemungkinan kebudayaan yang satu mempengaruhi kebudayaan yang lain sehingga dalam hubungan stratifikasi sosial ini sebaiknya diambil contoh suatu kebudayaan yang cukup tua dan mapan, dengan melihat pada kebudayaan yang relatif murni ini perbedaan golongan sosial yang ditampilkan lewat pakaian merupakan ciri universal, seperi kita ketahui kebudayaan Indonesia sejak dahulu telah mendapat pengaruh-pengaruh dari kebudayaan India, masyarakat Jawa yang dimaksud adalah mereka yang menggunakan bahasa Jawa sebagai bahasa ibu dan yang masih menjalankan nilai-nilai budaya Jawa baik kebiasaan prilaku mapun seremonial, Saat ini etnis Jawa telah menyebar hampir di segala penjuru Indonesia, ditinjau dari geografis masa lampau, kehidupan masyarakat Jawa ada di wilayah administrasi provinsi Daerah Istimewa Yogyakarta, Jawa Tengah dan Jawa Timur saat ini, masyarakat terbagi dalam Jawa pesisir Utara dan pedalaman, berdasar administrasi saat ini masyarakat Jawa pesisir meliputi eks keresidenan Pekalongan, Semarang, Tuban, dan Surabaya, sedangkan masyarakat Jawa pedalaman meliputi eks keresidenan Banyumas, Kedu, Yogyakarta, Surakarta, serta Madiun, Kediri, dan Malang, ketiga terakhir dikenal sebagai wilayah Mataram (Depdikbud, 1990: 164-167).

\section{Pakaian Raja/ Bangsawan}

Batik Saudagaran merupakan motif larangan dari kelompok umur keraton sehingga seniman dari kaum saudagar diminta menciptakan motif baru yang cocok dengan selera penduduk saudagar, mereka juga mengubah motif larangan sehingga motif tersebut bisa digunakan penduduk umum, desain batik saudagaran biasanya terkesan "berani" dalam penentuan bentuk, stilisasi atas benda-benda alam atau satwa, ataupun gabungan warna yang didominasi warna soga serta biru tua batik saudagaran menampilkan kualitas dalam proses pengerjaan dan kerumitan saat menyajikan ragam hias mengubah Batik Keraton dengan desain-desain rumit serta mengisinya dengan cecek (bintik) hingga terciptalah batik sangat indah (Utami, 2014:16).

Penguasa mengenakan kain jarit dengan panjang 7-8 kubik dan lebarnya 3 kubik, dimana laki-laki mengenakannya di sekeliling tubuh bawah mereka seperti mengenakan gaun, tetapi cukup longgar sehinga terkadang kakinya tampak saat berjalan bagian yang berada di depan lebih rendah dari bagian yang lain. Sabuk pengikat biasanya terbuat dari sutra dan berpola chindi atau patole. kotak sirih, salah satu perlengkapan yang harus ada, kotak sirih untuk pria dinamakan epok sedangkan kotak sirih perempuan disebut chepuri, Para pria atau wanita rambutnya tidak ada yang dipotong, tapi dibiarkan panjang alami berbeda dengan orang Bugis dan Melayu, yang mempunyai potongan rambut pendek kaum laki-laki, kecuali dalam acara tertentu, biasanya melingkarkan rambut mereka disekeliling kepala, dan menjepitnya dengan sisir sirkam di depan. Namun, di kalangan petinggi, merupakan satu kehormatan untuk membiarkan rambutnya terurai di hadapan atasan mereka, para pangeran dan penguasa di provinsi pribumi mengikat rambut mereka di leher dan membiarkan terurai mengikal di punggung, wanitanya menggulung rambut mereka menjadi satu ikatan di belakang kepala, ada beberapa bentuk dan nama yang berbeda untuk setiap cara menggulung saat rambut, poni pendek yang ada di dahi dipotong untuk memberikan kesan bersih saat rambut 
disisir ke belakang sementara rambutrambut pendek yang tidak bisa disisir atau diikat dibentuk keriting ikal, dan setiap orang meminyaki rambutnya para wanita memakai wangi-wangian di rambut, dan terkadang menghiasi rambut dengan bunga-bunga, jepit berlian dan perhiasan lain untuk acaraacara resmi. Ada beberapa jenis minyak wangi yang dipakai pria dan wanita seperti lang'a chandana (minyak cendana), lang'a kanang'a, lang'a garu, lang'a gandapura dan lang'a jeru, dan melumuri tubuh dengan semacam ramuan yang disebut bore yang terdiri dari bore kuning (bedak kuning), bore erang (hitam), bore sari dan bare k' lambak, ada juga minyak kesturi yang disebut dedes di rumah-rumah orang kaya biasanya dibakar dupa kayu-kayu wangi lain (Raffles, 2015:54-56).

\section{Pakaian Agamawan}

Pakaian agamawan berupa pakaian seperti rompi xicolli ini merupakan jaket berumbai-rumbai, menurut catatan terutama dipakai oleh para pendeta yang sekaligus membakar kemenyan pada tangan yang lain, rompi xicolli ini menarik disebut karena versi-versi modern rompi ini sering dipakai sebagai mode anak-anak muda zaman sekarang (Utami, 2014: 63-64).

Para ulama berpakaian putih dan memakai surban seperti orang Arab, sama seperti yang dikenakan penduduk di distrik Jawa, di distrik Barat atau Sunda, rakyat biasa tidak mendapat banyak bahan pakaian seperti wilayah pinggang di distrik Timur, penguasa pada acara-acara tertentu biasanya mengenakan topi yang disebut kuluk (Raffles, 2015:56).

\section{Pakaian Rakyat Biasa}

Laki laki dari kalangan bawah biasanya menggunakan celana kain selut, dengan jarit atau kain yang melilit pinggang dan menjuntai melewati lutut, seperti gaun atau pendek kain ini selalu diikat di pinggang dengan sabuk saat bekerja di sawah atau bepergian, tapi biasanya dilepas saat bertemu orang yang lebih kuasa umumnya orang Jawa memakai semacam kemeja pendek sepanjang siku yang disebut kalambi, warnanya putih atau bergaris-garis hitam putih, saputangan (ikat) dililitkan di kepala, pada orang melayu kain kepala ini biasanya bermotif kotak, tetapi orang orang Jawa menggunakan kain batik yang cara pemakaianya lebih menyerupai surban dibandingkan ikat kepala Melayu sekeliling kepala dililitkan kain ini dan ujungnya dimasukkan ketika bepergian jauh mereka biasanya menggunakan topi lebar dari bilah bambu yang dijalin, dan mampu melindungi mereka dari panas dan hujan, mereka menjinjing kantong kecil yang berisi tembakau, siri, dan lain-lain. Keris atau belati yang dipakaia semua kalangan menjadi pelengkap pakaian mereka bagi para perambah hutan biasanya membawa pisau besar atau golok untuk memotong kayu, rumput, atau dahan yang menggangu (Raffles, 2015:54).

Pakaiaan rakyat biasa adalah baju yang digunakan sehari-hari yang dipakai waktu istirahat, sesudah bekerja di ladang, bergantung pada kemampuan orangnya bagi mereka yang mampu, memakai payama atau baju pelembangan ada pula yang memakai kemeja tangan pendek, bahan pakaian terbuat dari bermacammacam kain, ada yang senang kain tipis supaya jagan merasa panas umumnya bahan pakaian ialah kain katun atau kain nilon ada juga yang memakai kain batik (Abu, 1990:23-25).

\section{Pakaian Nelayan/ Pemburu}

Mengambarkan seorang laki-laki sedang memanah burung, orang yang lain membawa busur dan batu mereka memakai kain pendek, dan kain kecil (Utami, 2014:101).

\section{Pakaian Petani}

Pada waktu dahulu kain yang digunakan untuk melakukan pekerjaan harian, seperti mengerjakan kebun selalu 
bercirikan warna putih bercampur hitam. Kain-kain ini tidak memiliki motif, warna yang menonjol bervariasi antara hitam dan putih namun pada kebanyakan orang lebih dominan warna putih, dilihat dari alasan penggunaan warna, menurut mereka kain dengan warna putih diselang-selingi warna hitam lebih cepat proses penenunannya dibanding dengan kain yang bewarna lainnya selain alasan ini juga dikatakan bahwa kain untuk melakukan kerja biasanya cepat kotor dan mudah rusak sehingga selalu harus diganti untuk musim-musim kerja ladang berikutnya. Berkaitan dengan hal ini dikatakan juga bahwa pekerjaan menenun yang biasanya dilakukan kaum wanita pada masa sesudah panen, selalu mengalami hambatan waktu, pada masamasa seperti itu, kaum wanita disibuki dengan tugas menenun kain-kain adat baik untuk laki-laki maupun untuk wanita untuk segala keperluan adat kawin dan lain sebagainya, kain kerja dengan warna putih biasanya dibuat dengan teknik benang lungsi warna putih diselingi satu dua warna hitam, sedangkan pada bagian pinggirnya diberi benang lungsing warna hitam yang berfungsi sebagai pinggiran atas dan bawah dari kain (Depdikbud, 1990:11-12).

Anak-anak petani yang berusia 15-18 bulan sampai umur 6-7 tahun biasanya telanjang, tetapi anak-anak dari kelas yang lebih tinggi mengenakan jarit di pinggang, dan jaket pendek, batik petani merupakan batik yang dibuat sebagai selingan aktivitas ibu rumah tangga saat waktu senggang atau tidak pergi ke sawah, batik petani disebut juga batik pedesaan atau batik pangan yaitu batik yang biasa digunakan oleh kaum petani, dimana pola-polanya tetap bersumber dari keraton yang kemudian diubah dengan ragam hias yang berasal dari alam sekitar, flora dan fauna, gambaran aktivitas sehari-hari seperti bertani (Raffles, 2015:54).

Ciri batik petani biasanya tidak halus motifnya yang beragam merupakan tradisi turun-temurun sesuai dengan daerah masing-masing biasanya sederhana karena pembuatannya tidak secara khusus terampil atau memproduksi batik, batik ini dikerjakan secara sambilan sehingga tidak professional pewarnaanya pun hanya dipasrahkan pada saudagar yang mejual bahan pewarna, jenis batik ini adalah salah satu pembuatan batik yang kurang kreatif. Karena itu, pembuatannya adalah mayoritas perempuan petani yang tidak membatik karena membatik buka mata pencaharian hidup mereka. Batik petani juga berkembang sejalan dengan perkembangan zaman bersumber dari pola-pola batik keraton, lahirlah pola-pola baru pada wastra batik petani dengan stilasi ragam hias bentuk alam sebagai contohnya adalah motif tumbuhan, buah, serangga, burungburung kecil dan lain-lain misalnya, pola buketan, hampir di semua daerah di Jawa muncul aktivitas produksi batik petani yang berkembang di daerah pesisir hasil produknya dikenal dengan wastra batik gaya pesisirnya (Utami, 2014:16).

Pakain kerja yang diuraikan dalam naskah ini ialah pakaian kerja di ladang, sawah atau di kebun, karena pakaian kerja di lapangan lain hampir sama dengan pakaian kerja suku-suku lain, untuk melindungi kepala pria dari panas matahari dan hujan dipakai tutup kepala terbuat dari daun nipah, rotan atau anyaman bambu, banyak juga petani yang bekerja di ladang tidak memakai baju sedangkan bagian bawah memakai celana panjang, sebagai pelindung kaki supaya jangan kena duri atau digigit lintah, bahannya dahulu kain belacu atau katun bewarna hitam, petani tradisional biasanya tidak memakai alas kaki (Abu, 1990:25-26).

\section{Pakaian Prajurit/Tentara}

Pakaian para tentara terdiri dari dhoti dengan lipatan-lipatan yang dijahit di belakang sehingga tidak menggangu gerakgeriknya, mereka juga memakai jas tangan panjang dan turban di kepala mereka, sebagai pengganti mantel dipakai sejenis 
blus pendek, hanya memakai ikat pinggang dan ikat kepala, pakaian khusus yang menunjuk pangkat adalah suatu mantel pakaian perang (Tilmatli) yang menjadi lambang status paling nyata dan paling diinginkan, corak mantel ini harus memilki syarat-syarat yang ketat sesuai dengan pangkat atau jasa seseorang di medan perang di samping mantel dan baju perang terdapat rompi khusus untuk baju upacara, ternyata ada enam kelompok sosial yang boleh memakai baju tersebut yautu: 1) dewa dewa dan yang mewakili mereka; 2) pendeta-pendeta; 3) bangsawanbangsawan; 4) tawanan-tawanan perang yang akan dikorbankan; 5) pedagangpedagang dengan budak belian yang akan dikorbankan; 6) pejabat pemerintah (administrator) (Utami, 2014:62-63).

Motif parang motif ini dikenal pamiliar sebagai pola pedang atau keris sedangkan masyarakat setempat menyebutnya lidah api atau motif parang lidah api, motif perang dibedakan menjadi dua macam yaitu:

a. Parang Rusak

Parang rusak diartikan sebagai pertarungan antara manusia melawan kejahatan dengan cara mengendalikan hawa nafsu dan keinginan mereka sehingga mereka menjadi mulia bijaksana, dan menang.

b. Parang Barong

Parang barong pada zaman dahulu hanya dipakai oleh raja dan dianggap sebagai pola yang suci, arti dari motifnya adalah siapa pun yang menjadi raja harus berhati-hati dalam menjaga dirinya sendiri agar dia menjadi seorang penguasa yang jujur, adil, dan bertangung jawab terhadap rakyatnya (Utami, 2014:20-21).

\section{Pakaian Seniman/Pemusik}

Pakaian pemusik seringkali menggunakan blus pendek dan dhoti yang dilipat di belakang dan jatuh sampai ke batas lutut mereka memakai topi tinggi, topi runcing atau sejenis peci atau topi keledai dan sepatu lars, sesuai dengan urutan contoh-contoh di atas, dapat dilihat bahwa pada umumnya pakaian itu memang disesuaikan menurut situasi (berburu, berperang), lingkungan (alam terbuka, hutan), dan stratifikasi sosial. Mengenai stratifkasi sosial ini memang nyata peraturan-peraturannya, dan untuk menjaga ciri-ciri kebesaran dan untuk mencegah ditiru masyarakat rendah sejak dahulu golongan atas selalu berusaha untuk membedakan cara berpakaiannya, yang sebetulnya sulit untuk dipertahankan di lain pihak kalangan masyarakat luas akan selalu berusaha meniru berpakaian golongan atas ini, dari catatan-catatan tentang kebudayaan Aztec yang dibuat oleh para misionaris, sebelum kedatangan bangsa Spanyol di Meksiko terdapat undang-undang berpakaian yang pada dasarnya menentukan hal-hal sebagai berikut, Pertama rakyat jelata hanya boleh memakai pakaian dari bahan sederhana; kedua hanya kalangan atas yang boleh memakai pakaian dari bahan yang eksklusif; ketiga hiasan tertentu yang diizinkan untuk pakaian kalangan atas; keempat pakaian wanita disesuaikan dengan status suami atau ayah kecuali untuk pendeta wanita (Utami, 2014:62-63).

Seorang pemusik berpakaian sederhana, pakaian yang digunakan adalah kain panjang yang lebar, selendang yang diikat di pinggang membentuk (seperti) pita sebagai pemain musik jalanan mereka memakai celana pendek dengan kain kecil di pinggang dengan wiru ujung kain di depan, tanpa perhiasan sedangkan rakyat biasa mengenakan kain yang diangkat pendek tampak seperi cawat, yang suatu pakaiannya serupa dengan pemain musik (Utami, 2014:91).

Mengenai konsep keindahan seorang laki-laki muda, akan diambilkan dari satu tulisan berjudul jaya langkara, yang mengambarkan keindahan dan nilai-nilai seorang pemuda yang baik; "keturunan seorang terhormat harus memenuhi tujuh syarat yang tidak boleh tertinggal, pertama, 
dia harus berasal dari keturunan yang baik; kedua, dia harus pintar; ketiga, bisa mengendalikan dirinya; keempat, dia harus menguasai sastra; kelima, mempunyai pandangan yang luas; keenam, harus tekun beribadah; ketujuh, bisa memanfaatkan semua kelebihannya tanpa ragu-ragu, inilah ketujuh hal yang harus diperhatiakan, pikirkan dan hatinya harus tenang dan seimbang, mampu mengendalikan diri dan diam apabila perlu, boleh sekali-kali berkata bohong dia tidak boleh tamak, dan juga tidak takut mati, dia tidak boleh tinggi hati, dan mampu menghibur yang sedang kesusahan semua yang dikerjakan akan langsung terlihat hasilnya, mampu menebak isi hati dan tujuan orang lain, cara berpikirnya harus pintar, waspada dan aktif. Ketika bertemu seseorang yang pintar, dia harus berguru dengannya sampai semua ilmu dapat dikuasai dalam setiap tindaknya harus mengutamakan kepentingan umum dibanding keinginannya sendiri selama hidupnya dia harus menimba ilmu, dan berhati-hati dalam setiap tindakannya ingatnnya jernih dan kuat, bicaranya lembut dan ramah sehingga orang tertarik, dan penguasa akan menghargainya, penampilannya dan sikap tubuhnya tidak boleh tercela tubuhnya harus indah seperti Batara Asmara (dewa cinta) yang turun ke Bumi ketika seseorang melihatnya, mereka akan berpikir 'alangkah bagusnya apabila dia ikut perang tidak boleh ada anggota tubuh yang cacat, warna kulitnya seperti emas mentah; kepalanya agak besar; rambutnya lurus dan panjang, matanya berkaca-kaca; alisnya seperti daun imbo; bulu matanya seperti bunga tanjung; hidungnya mancung dan tegak, mempunyai kumis tipis,bibirnya seperti mangga masak; giginya hitam dan terkilat seperti macan kumbang, dada dan bahunya lebar." Berdirinya harus tegap dan gagah apapun yang dia katakan akan berkesan bagi siapapun di sekitarnya, dan pendapatnya di dukung banyak orang" dia mengenakan celana chindi dan kain dodot berwarna hijau tua dengan motif gadong eng'ukup; sabuknya rendah emas kerisnya bergaya santrian, dan pegangannya bergaya tung'gaksmi. sumping (tiruan bungan yang digantung di tiap telinga) terbuat dari emas, dan berpola surengpati (berani mati); di ibu jari kanannya dia mengenakan cincin emas (Raffles, 2015:60-62).

\section{Pembahasan}

\section{Relevensi Seni Pakaian dalam Kebudayaan Mataram Kuno Sebagai Sumber Pembelajaran di SMA Nadhlatul Ulama Palembang Dengan Kurikulim Sejarah SMA}

Sejarah sebagai kisah atau catatan menggambarkan peristiwa sesuatu yang benar-benar terjadi masa lampau, oleh karena itu, untuk merekonstruksi kejadian-kejadian tersebut yang terjadi pada masa kerajaan Mataram Kuno haruslah disusun berdasarkan bukti yang merupakan peninggalan dari perbuatan manusia masa lampau, dari bukti itu disusun fakta yang merupakan pengungkapan tentang sesuatu keadaan atau peristiwa yang telah terjadi, peninggalan-peninggalan manusia dari masa lampau itu lazim disebut sebagai sumber sejarah.

\section{Sumber Tertulis (Sumber Dokumen)}

Sumber dokumen misalnya: koleksi yang meliputi; foto foto awal ditemukannya candi Borobudur, foto pemugaran pertama candi Borobudur, foto koleksi relief-relief pakaian candi Borobudur dan lain sebagainya.

\section{Sumber Benda (Artefak)}

Di museum Samudra Raksa antara lain: seluruh koleksi gerabah, keramik, manik-manik dan lain sebagainya yang didapatkan di sekitar komplek candi Borobudur.

\section{Sumber Lisan}

Misalnya, koleksi kaset dokumenter, intervie tersebut merupakan sumber lisan primer dan asli dari pelaku sejarah pada peristiwa penemuan dan pemugaran candi 
Borobudur.

Sumber rekaman; sumber rekaman berupa rekaman kaset audio, rekaman kaset video, rekaman kaset audiovisual.

\section{Pokok Temuan}

Peninggalan-peninggalan dari masa kerajaan Mataram Kuno yaitu relief pakaian pada candi Borobudur yang dapat dijadikan sumber pembelajaran siswa SMA berupa bangunan Borobudur dan juga relief pakaian pada candi Borobudur serta koleksi benda-benda peninggalan yang dipamerkan di dalam museum. Bangunan candi Borobudur dibagi menjadi tiga tingkatan. Tingkatan pertama yaitu Kamadhatu, tingkatan kedua yaitu Rupadhatu, tingkatan ketiga yaitu Arupadhatu, tingkatan pada candi Borobudur ini sangat erat kaitanntan dengan pembelajaran sejarah di SMA pada kelas $\mathrm{X}$ semester 1 .

\section{Relief Pakaian Pada Candi Borobudur Sebagai Sumber Pembelajaran dalam K13}

Konsep dasar K13, dalam Standar Nasional Pendidikan (SNP Pasal 1, ayat 15) dikemukakan bahwa K13 adalah kurikulum operasional yang disusun dan dilaksanakan oleh masing-masing satuan pendidikan. Penyusunan KT13 dilakukan oleh satuan pendidikan dengan memperhatikan dan berdasarkan standar kompetensi serta kompetensi dasar yang dikembangkan oleh Badan Standar Nasional Pendidikan (BSNP) (Mulyasa, 2007:19).

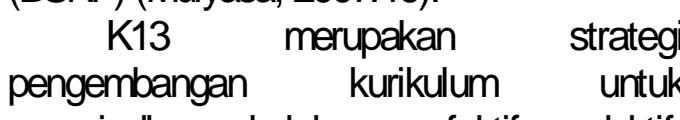
mewujudkan sekolah yang efektif, produktif, dan berprestasi. K13 merupakan paradigma baru pengembangan kurikulum, yang memberikan otonomi luas setiap satuan pendidikan, dan pelibatan masyarakat dalam rangka mengefektifkan proses belajar-mengajar di sekolah. Otonomi diberikan agar setiap satuan pendidikan dan sekolah memiliki keleluasaan dalam mengelola sumber daya, sumber dana, sumber belajar dan mengalokasikannya sesuai dengan prioritas kebutuhan, serta lebih tanggap terhadap kebutuhan setempat (Mulyasa, 2007:20).

K13 adalah suatu ide tentang pengembangan kurikulum yang diletakkan pada posisi yang paling dekat dengan pembelajaran, yakni sekolah dengan satuan pendidikan. Pemberdayaan sekolah dan satuan pendidikan dengan memberikan otonomi yang lebih besar, disamping menunjukkan sikap tanggap pemerintah terhadap tuntutan masyarakat juga merupakan sarana peningkatan kualitas, efisiensi, dan pemerataan pendidikan (Mulyasa, 2007:21). Kaitannya dengan keberadaan candi Borobudur, bahwa K13 memberikan keleluasaan yang luas pada sekolah-sekolah SMA khususnya mata pelajaran sejarah untuk mengelola museum sebagai media/sumber pembelajaran yang optimal mencapai tujuan pembelajaran sejarah maksimal. Keefektifan pembelajaran dipengaruhi oleh perbedaan individu siswa. Perbedaan tersebut antara lain perbedaan jenis kelamin, intelegensi, gaya belajar, sikap, ketertarikan pada sesuatu, motifasi, ketelitian, dan kesanggupan belajar termasuk perbedaan dalam siasat kognitif dan kecepatan belajar (Eddy, 2000:150).

Untuk mewujudkan tujuan pembelajaran, maka dibutuhkan kondisi yang ideal. Kondisi pembelajaran yang ideal adalah apabila siswa berinteraksi melalui serentetan pengalaman yang dirancang secara individual, interaktif, sampai pada tingkat tujuan pembelajaran yang berhasil diraih.

Candi Borobudur sangat efektif dan representatif jika dimanfaatkan sebagai sumber pembelajaran karena di dalam kopmplek candi Borobudur selain pengajaran materi sejarah yang disampaikan dengan ceramah siswa juga menyaksikan gambar-gambar foto, bendabenda peninggalan yang digunakan pada 
peristiwa zaman dahulu. Siswa diberi kesempatan untuk melihat, mengamati, dan menanyakan langsung terhadap materi yang belum diketahui/belum jelas. Hal itu memungkinkan siswa untuk berpikir kreatif, menemukan konsep-konsep baru tentang materi, sehingga memudahkan siswa untuk mengerti dan memahami materi yang disampaikan dan tidak mudah begitu saja melupakan.

Pemanfaatan sumber pembelajaran oleh guru maupun siswa mengandung arti yang positif karena dengan cara yang terkoordinasi dengan baik di bawah satu lembaga, para siswa dapat memanfaatkan berbagai fasilitas yang ada pada pusat pembelajaran tersebut dengan leluasa, demikian juga dalam pemanfaatan museum Samudra Raksa sebagai sumber pembelajaran, siswa dapat berkunjung secara individu maupun kelompok tanpa harus disertai atau tidak disertai seorang guru. Siswa dapat melihat, mengamati, mengidentifikasi, dan menginterpretasikan secara medetail semua benda-benda peningalan masa kerajaan Mataram Kuno untuk memperkaya pengetahuan sejarah.

\section{Nilai Sejarah Seni Pakaian Pada Kebudayaan Mataram Kuno Sebagai Sumber Pembelajaran Sejarah}

Kenyataan dalam masyarakat pakaian dikenakan orang di samping sebagai pelindung badan terhadap pengaruh alam sekelilingnya, seperti pelindung badan terhadap panas, dingin, gangguan binatang-binatang kecil, tumbuhan-tumbuhan yang berbahaya dan lain-lainnya, pakaian juga mempunyai fungsi estetika, dalam prosesi secara keseluruhan dan fungsi etika dengan melindungi bagianbagian badan tertentu. dengan demikian fungsi pakaian dan perhiasan sebagai berikut: 1) melindungi tubuh dari udara luar; 2) menyembunyikan kekurangan; 3) menampilkan kelebihan; 4) menunjang dan membentuk kepribadian; 5) menghias diri;
6) menunjukkan status sosial (Utami, 2014:10).

Kain pada dasarnya berfungsi sebagai pelindung tubuh dari teriknya matahari dan dinginnya udara, namun di Indonesia keberadaan kain telah menjadi identitas dan lambang status sosial-budaya tiap daerah, masyarakat lebih mengenalnya dengan sebutan batik hampir semua daerah memiliki jenis batik atau pakaian/busana masing-masing yang berkarakter dan bernilai tinggi batik merupakan warisan nenek moyang Indonesia (Jawa) yang sampai saat ini masih ada, batik pun merupakan ikon penting budaya Indonesia yang memiliki nilai seni tinggi dan telah menjadi bagian yang tidak terpisahkan dari kehidupan sosial, budaya, dan adat masyarakat sehari-hari, kekayaan produk budaya seperti ini merupakan kebanggaan yang harus dijaga kelestarian dan keeksistensinya karena hanya di Indonesia kain batik berada (Utami, 2014:2).

Kecuali membuat pakaian dari kulit kayu, mereka sudah pandai menenun tekstil yang agak halus, karena tekstil terbuat dari bahan yang mudah lupuk, maka tak ditemukan bekas-bekasnya, bukti adanya kemahiran menenun ialah dengan diperolehnya petunjuk nyata dari periuk belanga yang berasal dari zaman itu yang memakai hiasan tenunan. Perpaduan antara kepandaian membuat pakaian masa prasejarah dengan kepandaian menenun corak ragam hias ini yang nanti akan menerima anasir-anasir Hindu maupun Budha, dan akan berkembang sesuai dengan perbedaan masa serta alam lingkungannya (Utami, 2014:10-11).

\section{SIMPULAN}

Seni pakaian dalam kebudayaan Mataram Kuno dibedakan menjadi 7 sebagai berikut: golongan pertama adalah kaum bangsawan dengan gaya pakaiannya menggunakan bahan-bahan infor dari luar negeri, golongan kedua yaitu golongan agamawan dengan gaya pakaiannya 
menggunakan kain yang panjang seperti kemban yang dililitkan di badan tanpa menggunakan motif apapun melambangkan kesucian, golongan ketiga yaitu golongan rakyat biasa dengan gaya pakaianya berdasarkan dari hasil pembuatan sendiri dari bahan-bahan yang sederhana, golongan ke empat yaitu golongan petani dengan gaya menggunakan bahan-bahan yang halus agar tidak terasa panas saat mengerjakan pekerjaan kebun, golongan kelima yaitu golongan tentara/prajurit dengan gaya pakaian mengunakan mantel atau tanda pengenal dari kerajaan, golongan ke enam yaitu golongan pemburu dengan gaya pakaian mengunakan celana pendek dan baju pendek agar bebas dalam pekerjaan pemburu, golongan yang ke tujuh yaitu golongan pemusik dengan gaya pekaiannya yang glamor dan indah agar dapat menarik perhatian orang.

\section{DAFTAR FUSTAKA}

Abu, Darda Hanafi, Dkk. 1990. Pakaian Adat Tradisional Kalimantan Timur. Jakarta.

Depdikbud. 1990/1991. Pakaian Adat Tradisional Daerah Propinsi Nusa Tenggara Timur. Yogyakarta.

Eddy, Sutadji. 2000. "Pengembangan Modul Pembelajaran Individu Untuk Meningkatkan Kualitas dan Hasil Pembelajaran dalam Mata Kuliah Pengetahuan Bahan". Jurnal Pendidikan dan Kebudayaan. Malang: IKIP.

Endraswara dan Suwardi. 2015. Etnologi Jawa (Penelitian Perbandingan Dan Pemaknaan Budaya). Jakarta.

Handoyo. 2015. Studi Masyarakat Indonesia. Yogyakarta: Ombak.

Koentjaraningrat. 2009. Pengantar IImu Antropologi. Jakarta: Rineka Cipta.

Mulyasa. 2003. Kurikulum Berbasis Kompetensi Konsep, Karakteristik, dan Implementasi. Bandung: PT. Remaja Rosdakarya.
Raffles, Thomas Stamfrod. 2015. The History Of Java. Yogyakarta: Narasi.

Utami, Riski. 2014. Ensiklopedia Batik Dan Kain Hias Nusantara. Bandung: Angkasa. 